\title{
Defining a taxonomy of employability skills for 21st-century higher education graduates
}

\author{
Ornellas, Adriana ${ }^{a}$
}

${ }^{a}$ Faculty of Psychology and Education Sciences, Universitat Oberta de Catalunya, Spain.

\begin{abstract}
This paper aims to discuss the theoretical development and the practical validation of a taxonomy of skills for boosting new graduates employability at Higher Education Institutions (HEI).
\end{abstract}

The taxonomy was developed within the framework of the project Skill Up: Matching graduates' skills and labour world demands through authentic learning scenario. The project, funded by the Erasmus+ programme of the European Union, is a strategic partneship in the field of Higher Education (HE) that involves six partners (four universities, a VET (Vocational Education and Training) school and an employer representative) from three European countries (Spain, Sweden and Germany).

For the definition and validation of the taxonomy two methods were applied: a) a literature review of studies and reports that in recent years have established different frameworks and lists of skills crucial for HE graduates to acquire; b) an asynchronous online focus group involving various stakeholders (undergraduates, graduates, employers' representatives, lecturers and counsellors) to validate the taxonomy.

The paper presents the resulting list of employability skills sorted into four clusters: cognitive, methodological, social and subject-specific.

Keywords: Employability skills; Taxonomy; Higher Education; Graduate. Soft skills. 


\section{Introduction}

This paper gives an account of some of the results obtained in the first phase of the project Skill Up: Matching graduates' skills and labour world demands through authentic learning scenarios ${ }^{1}$. The project aims to build scalable and replicable ways for connecting higher education (HE) curricula with evolving labour market demands through a strategic partnership that involves six institutions: four universities, a vocational education and training (VET) school and an employer representative from three European countries (Spain, Germany and Sweden). The specific objectives of the project are to:

- $\quad$ Map good practices in matching graduates' skills and labour market demands through authentic learning scenarios in partners' HE settings.

- Improve soft and hard employability skills of undergraduates by means of designing, developing, applying and evaluating authentic learning scenarios in various HE and VET programmes identified by partners as priorities.

- Enhance access to career counselling and guidance services for undergraduates by training tutors in career counselling, with emphasis on ecounselling.

- Implement and promote a virtual environment that acts as a hub for attracting stakeholders, offering guidance to labour market newcomers and real handson experiences in the professional world as part of students' learning.

The results presented here consist of a taxonomy of employability skills crucial for HE graduates to acquire that was classified into fours clusters: cognitive; methodological; social and subject-specific. Moreover, the competence-centred approach to the concept of employability skills adopted in the project is discussed.

\section{Theoretical framework}

There are many definitions and approaches established for employability. From an employment-centred perspective, Hillage and Pollard (1998) point out that employability is about three abilities: gaining initial employment; maintaining employment; and obtaining new employment if required.

Yorke (2006) in turn, from a competence-centred approach, defines employability as:

[...] a set of achievements - skills, understandings and personal attributes - that makes graduates more likely to gain employment and be successful in their chosen

\footnotetext{
${ }^{1}$ The project is funded by the Erasmus + programme of the European Union. More information is given in the website of the project: skill-up-project.eu.
} 
occupations, which benefits themselves, the workforce, the community and the economy (p. 8).

Along similar lines, defining the term "skills" is also a challenge. Often, the terms "skill" and "competence" are used interchangeably, when they are not necessarily synonymous (Cinque, 2016).

The European Qualifications Framework $(\mathrm{EQF})^{2}$ provides a grid of eight reference levels based on learning outcomes which are defined in terms of knowledge, skills and competence, where:

- "Knowledge" means the body of facts, principles, theories and practices that is related to a field of work or study and is described as theoretical and/or factual;

- "Skills" means the ability to apply knowledge and use know-how to complete tasks and solve problems and are described as cognitive (involving the use of logical, intuitive and creative thinking), and practical (involving manual dexterity and the use of methods, materials, tools and instruments); and

- "Competence" means the proven ability to use knowledge, skills and personal, social and/or methodological abilities, in work or study situations and in professional and personal development, and is described in terms of responsibility and autonomy.

In a similar vein, the Tuning project ${ }^{3}$, which offers a concrete approach to implement the Bologna Process in HE institutions and subject areas, defines competence as "a dynamic combination of knowledge, understanding, skills and abilities".

This work takes a competence-centred approach to the concept of employability skills, as formulated in Yorke (2006), understood as a combination of personal qualities and beliefs, knowledge, skilful practices and the ability to reflect critically and productively on experience, and that need to be frequently renewed during a person's working life. Also assumes a critical position in accordance with Waltz (2011) who asserts that to truly prepare and empower graduates to enter the labour market, it is important to discuss issues beyond the values of corporate managers such as employee rights, explorations of personal values, and critical analysis. Otherwise, we risk encouraging graduates "to believe that becoming and staying employed requires turning themselves into 'products' that conform to ever-changing market desires, which is certainly not a concept that should be left unchallenged" (Waltz, 2011: 4).

2 https://ec.europa.eu/ploteus/en/content/descriptors-page

3 http://www.unideusto.org/tuningeu/competences.html 


\section{Methodology}

To define and validate the taxonomy of employability skills in the first phase of the Skill Up project two main methods were used: a systematic review of current literature and an assyncronous online focus group.

The literature review at a European and international level aimed to build the concept of employability skills and to gather information from a variety of studies and reports that in recent years have established lists of skills crucial for higher education graduates to acquire.

The asynchronous online focus group involving 29 stakeholders (teaching staff, undergraduates, graduates, career counsellors and employers' representatives) from the three partner countries (Spain, Germany and Sweden) aimed to discuss the findings from the first cycle of the project and also to validate the taxonomy of employability skills defined. Considering that the group's degree of homogeneity is a key factor in maximizing disclosure among participants (Morgan, 1998), we established the following four groups, hoping to help the discussion flow better:

- First group: comprising nine labour market representatives.

- Second group: comprising six lecturers from HE and VET institutions.

- Third group: comprising nine graduates and students' representatives.

- Fourth group: in which five career counsellor representatives participated.

The online asynchronous focus group was chosen as a method to collect data much more quickly and at a lower cost than a face-to-face focus groups producing similar amounts and quality of information. It was developed in a Moodle platform and hold over the course of four days, with participants choosing when it would be most convenient to participate in the activities. A time dedication of thirty minutes per day with a total of two hours over the four days was estimated, similar to the time they had dedicated to a face-to-face focus group.

\section{Findings}

As a result of the literature review and taking into account the most current international reports, frameworks and studies reviewed (Davies et al., 2011; Haselberger et al., 2012; Humburg et al., 2013), a list of twenty employability skills required to promote graduates' employability was defined a priori (Figure 1). To define this list, we have considered those skills that are vital for success in the workplace and that should be developed mainly throughout HE training. Therefore, we have not included those skills that from our point of view should be acquired throughout compulsory education (i.e. basic skills). 


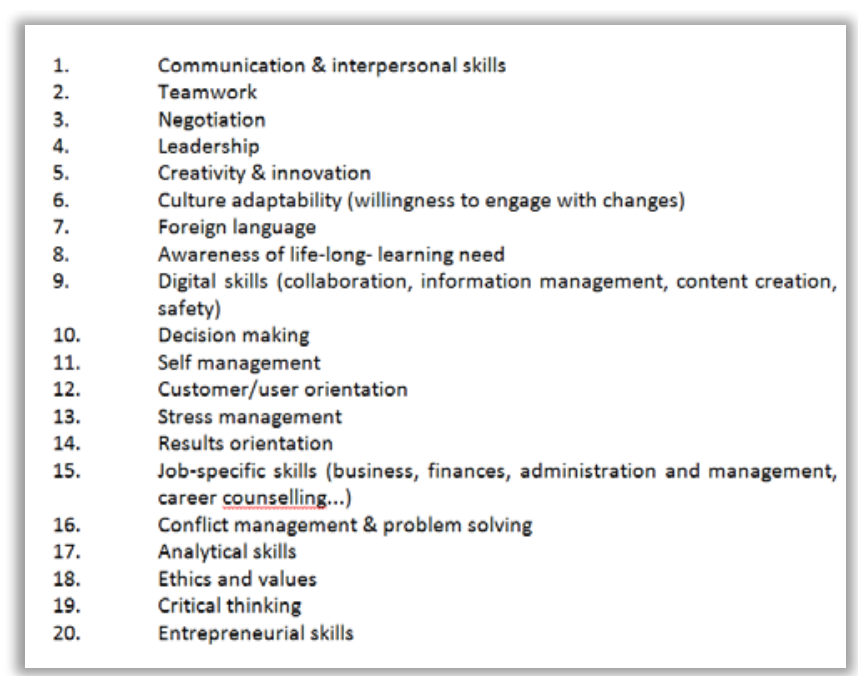

Figure 1. Set of skills emerged from the literature review. Source: own elaboration.

On the basis of this list of skills the online focus group activitites were formulated including an engagement questtionaire to know how the different stakeholders taking part perceived the importance of these skills for new graduates in order to be employable.

Some remarkable results of the questtionaire regarding the perceived importance of the skills show that counsellors representatives were unanimous in rating as the most important ones communication and interpersonal skills, culture adaptability and digital skills. Communication and interpersonal skills were also the most rated for the group of students and graduates together with foreign language and followed by teamwork and self management. For their part, lectures best rated teamwork, job-specific skills and critical thinking. Employers' representatives preference were negotiation, customer/user orientation, conflict management and problem solving and ethics and values.

The questionnaires also included questions regarding the skills that new graduates are most lacking. The group of students and graduates was unanimous in highlight their gap in skills related to foreign language. It was also commented that "skills such as communication, selfmanagement, teamwork or critical thinking were not taught by professors, instead it is "something you need to learn by yourself in order to successfully manage your studies". In their turn, lectures and employers' representatives agreeing on pointing out that students and new graduates need to improve in communication and interpersonal skills. Employers' representatives also refered to self management, decision making, team work ethics and values. 
Considering the results which have emerged from the questtionaires and from the subsequent discussion in the Moodle forum of the four groups of stakeholders, a new list of employability skills relevant for new graduates from the perspective of both the worlds of education and work was established. The new list have merged some skills considered as similars and also have disregarded the skills more likely to be developed throughout professional life (i.e. leadership or negotiation). The resulting list was sorted into four clusters: cognitive, methodological, social and subject-specific (Table 1).

Table 1. Taxonomy of employability skills required for HE graduates.

\begin{tabular}{|c|c|c|}
\hline & Skill & Definition \\
\hline \multirow{3}{*}{ Cognitive } & Analytical thinking & $\begin{array}{l}\text { Gathering, analysing and articulating information } \\
\text { from different sources and using it to solve problems } \\
\text { and make decisions efectivelly. }\end{array}$ \\
\hline & Creative thinking & $\begin{array}{l}\text { Thinking outside the box in order to bring new ideas } \\
\text { to solve problems or seek solutions to a particular } \\
\text { situation. }\end{array}$ \\
\hline & Foreign language & $\begin{array}{l}\text { Performing in a language different from the mother } \\
\text { tongue. Also includes intercultural understanding. }\end{array}$ \\
\hline \multirow{4}{*}{ Methodological } & Learning to learn & $\begin{array}{l}\text { Effectively managing one's own learning process and } \\
\text { needs, identifying available opportunities, and } \\
\text { overcoming obstacles in order to learn successfully } \\
\text { (European Commission, 2006). }\end{array}$ \\
\hline & Problem-solving & $\begin{array}{l}\text { Engaging in the actions or thoughts necessaries to } \\
\text { find solutions to a difficult or complex question or } \\
\text { situation and resolve conceptual problems. }\end{array}$ \\
\hline & Decision-making & $\begin{array}{l}\text { Thinking of several choices when an important } \\
\text { decision must be made, finding relevant information } \\
\text { to make a good choice and predicting the } \\
\text { consequences of the decisions taken for others. }\end{array}$ \\
\hline & Digital skills & $\begin{array}{l}\text { Being digitally competent in } 4 \text { areas (Vuorikari et al, } \\
\text { 2016): a) information and data literacy; b) } \\
\text { communication and collaboration; c) digital content }\end{array}$ \\
\hline
\end{tabular}




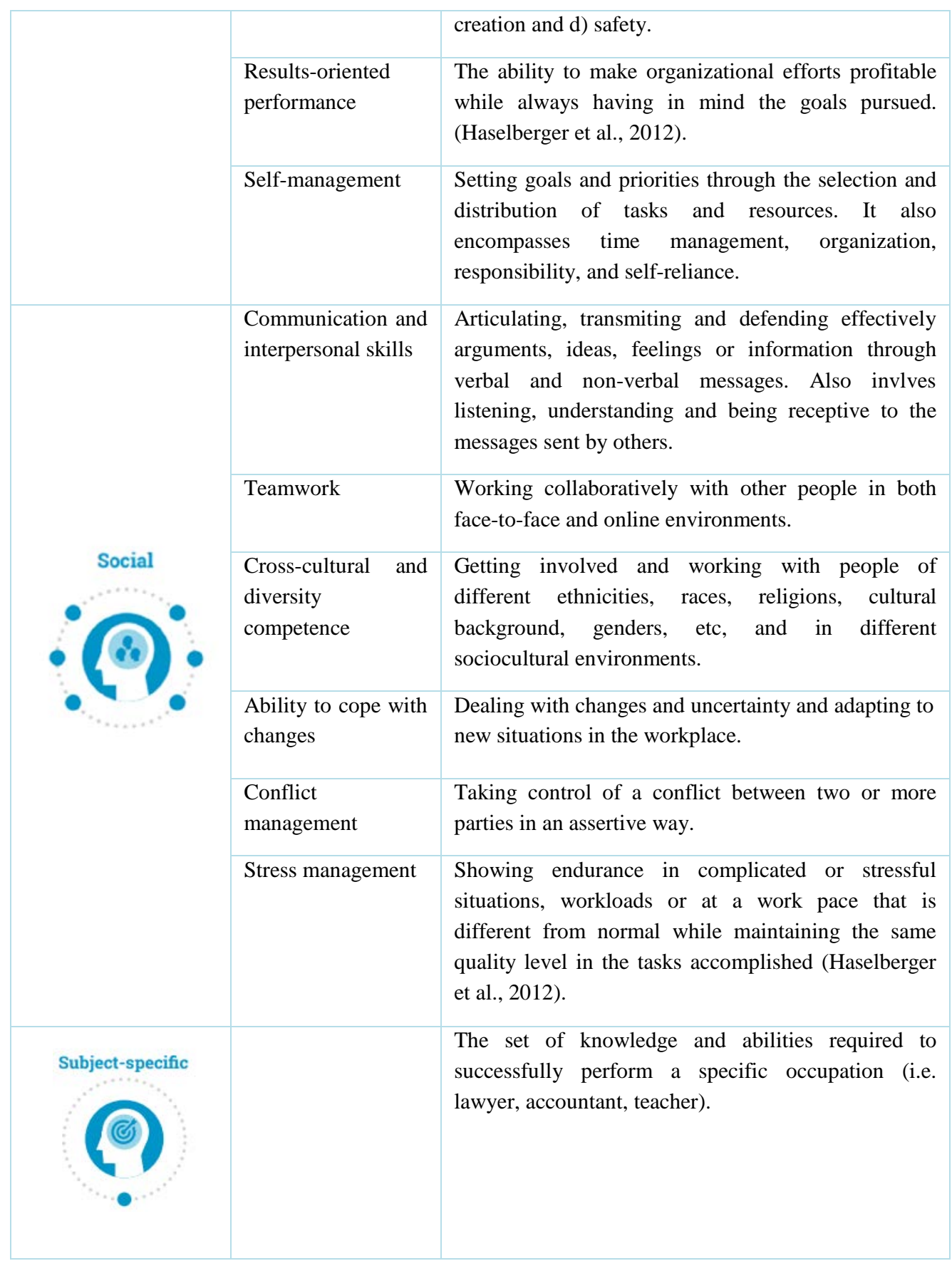

Source: own elaboration. 


\section{Conclusions}

First of all it should be mentioned that the results presented here are embedded in a wider framework designed in the first phase of the Skill Up project. The most important contribution of this study is the taxonomy of employability skills defined. This taxonomy is not intended to be a definitive list but a starting point for carrying out a more in-depth analysis of the supply and demand of new graduates' employability skills at European and partner countries national levels. The taxonomy also aims to give directions to higher education institutions on how to enhance graduates employability skills by improving the connection between HE curricula with the demands of the professional world. From the perspective of employability as a process or something to be achieved (Reid, 2016) this implies assuming the list of skills not just as an attribute of the new graduates but as something that need to be permanently renewed throughout a person's professional life.

\section{References}

Cinque, M. (2016). "Lost in translation”. Soft skills development in European countries. Tuning Journal for Higher Education, Vol 3, No 2, pp. 389-427.

Davies, A., Fidler, D., Gorbis, M. (2011). Future work skills 2020. Accessed May, 2017, http://www.iftf.org/futureworkskills.

European Commission (2006). Recommendation of the European Parliament and of the Council of 18 December 2006 on key competences for lifelong learning. Brussels: European Commission.

Haselberger, D., Oberhuemer, P., Pérez, E., Cinque, M. and Capasso, F. (2012). Mediating Soft Skills at Higher Education Institutions. Guidelines for the design of learning situations supporting soft skills achievement. Accessed April, 2017, http://www.modesproject.eu/en/the-modes-handbook.aspx.

Hillage, J. and Pollard, E. (1998) Employability: developing a framework for policy analysis. London: Department for Education and Employment.

Humburg, M., van der Velden, R. and Verhagen, A. (2013). The employability of higher education graduates: the employers' perspective. European Commission.

Morgan, D. L. (1998). Planning focus group. Thousand Oaks, California: Sage.

Reid, J. (2016). Redefining Employability as something to be achieved: Utilising Tronto's conceptual framework of care to refocus the debate. Higher Education, Skills and Work-Based, Learning, Vol. 6 No 1, pp.55-68.

Vuorikari, R., Punie, Y., Carretero Gomez S., Van den Brande, G. (2016). DigComp 2.0: The Digital Competence Framework for Citizens. Update Phase 1: The Conceptual Reference Model. Luxembourg Publication Office of the European Union. EUR 27948 EN. doi:10.2791/11517.

Yorke, M. (2006). Employability in higher education: what it is - what it is not. The Higher Education Academy Learning \& Employability. Series 1, York: THEA.

Waltz, M. (2011). Improving students employability, E-book. www.jobs.ac.uk. 